\title{
Spain, Catalonia, and the Supposed Authority of the Judiciary
}

\section{On the Self-constitutive Moment in Adjudication}

\author{
Maurits Helmich ${ }^{1}$ (D) \\ Published online: 9 September 2020 \\ (C) The Author(s) 2020
}

\begin{abstract}
Normative literature on the Catalan crisis is largely occupied with the conflict's central legalistic problem: can political units like Catalonia be allowed to split off from Spain unilaterally? This article reframes the issue and asks why secessionist Catalans should ever abide by Spanish legal constraints, given that Spanish law is precisely the institution they are politically trying to get rid of. It focuses on the anti-secessionist role played by the Spanish Constitutional Court between 2010 and 2017 and studies three arguments why Catalans supposedly have to accept the Court's authority. The article contends that two arguments - the "mutual benefit argument" and the "law and democracy" argument—will not be independently persuasive to Catalan secessionists. Instead, the Constitutional Court's authority must ultimately be grounded in a different type of argument: the "law and order argument." Secessionist Catalans' supposed duty to obey the orders of the Constitutional Court is ultimately not rooted in a positive service provided by the Court, but in the disruptive effects of disobeying. That exposes an explanatory defect in Joseph Raz's influential theory of authority, which seeks to ground authority exercises in a concept in prior reason or their capacity to make our life better. That conceptualization misses the key decisionistic element to political authority: its capacity to constitute our reasons, that is, to define the terms that give meaning to our evaluations.
\end{abstract}

Keywords Catalan crisis · Decisionism $\cdot$ Joseph Raz $\cdot$ Political authority $\cdot$ Secession $\cdot$ Service conception

Maurits Helmich

helmich@law.eur.nl

1 Erasmus School of Law, Rotterdam, Netherlands 


\section{Introduction}

Three years after Catalonia's attempt to split from Spain in October 2017, political relations between separatist Catalans and unionist Spanish are still in a complete deadlock. Though most politicians and commentators think that the dispute should be peacefully resolved through dialogue in accordance with (Spanish) law, a crucial question has mostly been left unanswered. Why should secessionist Catalans ever care to show obedience towards Spanish constitutional-legal institutions, now that those are precisely what they are politically trying to get rid of? The controversy has especially re-erupted since October 14, 2019, when the Spanish Supreme Court convicted several Catalan leaders for their role in the 2017 independence movement. Despite human rights complaints raised by the Catalan Ombudsman, ${ }^{1}$ Amnesty International, ${ }^{2}$ the UN Working Group on Arbitrary Detention, ${ }^{3}$ and International Trial Watch, ${ }^{4}$ nine Catalan separatist leaders were convicted to 9 to 13 years in prison. ${ }^{5}$ Popular protests followed, with hundreds of thousands of people to gathering on the streets in Barcelona and other places demanding freedom for (what the secessionists see as) the political prisoners. Although most protests happened peacefully, there were also riots. Within a week, there were 593 reported injuries. ${ }^{6}$ In total, four people lost an eye due to rubber bullets fired by police forces, and 65 journalists were injured, leading to condemnations from the Council of Europe and Amnesty International. ${ }^{7}$

Despite these excesses, it seems fair to say that the mainstream political voice does not share the core of the Catalan secessionist sentiments. Carmen Calvo, Spain's Deputy Prime Minister, called the police interventions "very proportional" and urged the Catalan independence movement to stop "lying" about having a right to self-determination. ${ }^{8}$ Likewise, Prime Minister Pedro Sánchez praised the "exemplary efforts and bravery of the Catalan police," calling it "absurd" to denounce a police force for performing its duty. ${ }^{9}$ The Supreme Court judgment that spurred all the anger, Spanish commentators assure us, was "not a political decision," $"$ and merely "enforcing the law." "11 That fits a wider international pattern of deference to Spanish constitutional authority. With a few exceptions, ${ }^{12}$ most influential European politicians (including Jean-Claude Juncker, Donald Tusk, Emmanuel Macron, Angela Merkel, and Boris Johnson) have spoken out in support of Spanish law enforcement. Similarly, many academic commentators lament Catalan anti-constitutional attitudes. ${ }^{13}$ Indeed,

\footnotetext{
${ }^{1}$ de Síndic (2018), esp. sect. 3.

${ }^{2}$ Amnesty International (2018); Amnesty International (2019b).

${ }^{3}$ Human Rights Commission (2019).

${ }^{4}$ International Trial Watch (2019a); International Trial Watch (2019b).

${ }^{5}$ For the judgment: Spanish Supreme Court, 459/ 2019.

${ }^{6}$ Stokes and Shields (2019).

${ }^{7}$ Amnesty International (2019a); Commissioner for Human Rights (2019).

8 Jones and Burgen (2019).

${ }^{9}$ Sánchez (2019).

${ }^{10}$ As says member to the Catalan Parliament Santi Rodríguez Serra, calling the Amnesty report on the trial “propaganda.” See CatalanNews (2019).

${ }^{11}$ Cabanas 2019.

12 An example of such an exception is Scottish MEP Alyn Smith, who unequivocally condemned to Supreme Court verdict: "This is a political verdict in a political trial. Pursuing self-determination through democratic, peaceful means is never a crime." See Smith (2019).

${ }^{13}$ E.g., Garrido-Muñoz (2018); López-Basaguren (2019).
} 
scholars have criticized the Catalan secessionist movement for its mass-indoctrinating, ${ }^{14}$ its anti-federalism, ${ }^{15}$ and its nationalist identity politics. ${ }^{16}$

The normative literature on the Catalan crisis is above all occupied with the conflict's central legalistic problem: can we allow political units like Catalonia to disobey legal constraints ${ }^{17}$ This article does not engage with this procedural legitimacy question. Instead, it addresses another issue, which was already mentioned at the beginning of this section. Even if we accept that there are procedural constraints to legitimate secession, why should Catalan secessionists ever accept those specific constraints coercively imposed by Spanish legal authorities? Specifically, the piece focuses on the ideological role played by one important actor in the Spanish-Catalan dispute: the Spanish Constitutional Court (hereinafter: "SCC"). Between 2010 and 2017, the SCC repeatedly took a centralist-Spanish stance, blocking Catalan attempts to seize more autonomy. Why would those who believe in the project of an independent Catalan state care to obey the SCC's directives, other than out of mere fear of repercussions? Dominant philosophical theories of authority, the article argues, cannot answer this question in a non-circular manner, because they seek to ground the concept in (prior) reason. That conceptualization misses the key decisionistic element to political authority: its capacity to constitute our reasons-i.e., to define the terms that give meaning to our evaluations.

In unpacking its argument, this piece proceeds as follows. First, it starts by offering a brief historical account of the dispute (Section 2). Over the years, I show, the SCC performed a key role in the constitutional conflict, declaring illegal several unilateral Catalan steps towards more autonomy. Subsequently, I argue that Joseph Raz's framework of law as a claim to supreme authority possesses particular power in explaining the repressive role Spanish authorities played during the conflict (Section 3). In claiming legitimacy for itself, Raz's account shows, law excludes ("preempts") perspectives that are foreign to it. The question remains, however, why Catalans with separatist sympathies should ever accept Spanish law's claim to legitimate authority. I propose there are roughly three candidate reasons. The first two - the "mutual benefit argument" and the "law and democracy argument"- offer useful insights, but do not suffice to give a credible grounding to Spanish authorities independently (Section 4). For this reason, the article argues that the Spanish perspective is best reconstructed as founded upon a "law and order argument" (Section 5). The need to safeguard political stability, the point is, can in itself be a meta-argument not to shake up existing constitutional arrangements in favor of purportedly more legitimate alternatives. Even when the ethical foundations of political society are shaking, there is still one proper role left for authority: to restore order and lead everybody to move into the same direction again. This is a crucial feature of authority, not only in times of crisis, but also under more ordinary circumstances (Section 6).

\footnotetext{
14 Tobeña (2017).

${ }^{15}$ Ruiz Devesa (2018).

16 Jones (2017); Delanty (2019).

${ }^{17}$ Indeed, whether a desire for regional autonomy can legitimately be enforced by means of secession remains a cause for controversy. "Primary right" or "choice" theorists believe so and generally argue that only constraints of human rights and political feasibility can override this right (e.g., Philpot 1995; Copp 1998). "Remedial right" or "just cause" theorists deny this and think that only special circumstances like mass killings or occupation can justify unilateral secession (e.g., Buchanan 1997; Norman 2003). All theorists do seem to agree, however, that there is a need for constitutional democracies to recognize and take seriously desires to self-government.
} 


\section{A History}

Catalan nationalism as such is old and has prominently existed since the days of Francisco Franco and before. The broad support for secession, however, is a relatively recent phenomenon. ${ }^{18}$ Before 2010, secessionism in Catalonia was relatively scarce, backed only by a minority of $20 \%$ of the domestic population of Catalonia or less. ${ }^{19}$ But since then, popular support for independence over alternative constitutional arrangements has risen significantly, peaking at $48.5 \%$ in $2013 .^{20}$ This sudden trend may be ascribed to a variety of long-term developments, but some more proximate causes likely exerted influence. For example, the economic crisis of 2008 and the austerity measures pushed through by the central government may have triggered Catalan resentment, stimulating secessionist Catalan parties to exploit latent nationalist sentiments. ${ }^{21}$ Or, more generally, Catalan populism may result from the unresponsiveness of the Spanish central government to demands for autonomy, ${ }^{22}$ especially after the rise of Mariano Rajoy's “anti-Catalan" People's Party. ${ }^{23}$ But one event has especially drawn much attention and is often cited as the direct cause for the present outrage: the judgment of the SCC regarding the Statute of Autonomy of Catalonia of 2006 (hereinafter: "the 2006 Statute"). ${ }^{24}$

Also known as Organic Act 6/2006 of July 19, ${ }^{25}$ the 2006 Statute concerns a reform of the older 1979 Statue and arranges the legal position of the Autonomous Community of Catalonia under the Spanish Constitution (hereinafter: "SC"). Drafted and passed by the Catalan Parliament (hereinafter: "CP") in 2005, the general aim was to expand the symbolic and legal-political autonomy of Catalonia. Among other things, a more central place was assigned to the Catalan language (Art. 6.1), and independent tax-raising powers were attributed to the CP (Art. 218.2). ${ }^{26}$ After extensive negotiations in Spanish parliament, an amended version of the draft was passed and ratified through a referendum back in Catalonia (78\% voted in favor, $22 \%$ against). It was only after the Spanish People's Party - one of the two parties voting against the reform - challenged the constitutionality of the 2006 Statute that the SCC came into play. Consequently, the latter was put in an extremely sensitive position, while being unable to rely on too much direct precedent. $^{27}$

The Court took 4 years to rule on the matter in 2010, a length of time which in itself was cause for frustration and rising tensions. ${ }^{28}$ And although the SCC's decision in and of itself displayed relatively little judicial activism, declaring unconstitutional "only" fourteen of the

\footnotetext{
${ }^{18}$ Guibernau (2013), 380.

${ }^{19}$ Griffiths et al. (2015), 47-48.

${ }^{20}$ CEO (2013), 26, q. 28. Admittedly, numbers have dropped again. In March 2020, popular support for independence compared to other constitutional solutions was reported to be "only" $33.9 \%$ among Catalans (CEO 2020, 29, q. 33). When posed as a simple yes/no question, $42.0 \%$ of the Catalans is in favor of independence (CEO 2020, 29, q. 34).

${ }^{21}$ Dowling (2014); Rico (2012), 219; Mueller (2019), 147.

${ }^{22}$ Guibernau (2013), 381.

${ }^{23}$ Coufalová (2017), 145-151.

${ }^{24}$ CCJ 31/2010; cf., e.g., Guibernau (2013), 382; Cardús (2013), 98; Perales-Garcia (2013), 110-111; Bosch (2013), 115-116.

${ }^{25}$ Official translation of the full text available at: https:/www.parlament.cat/document/cataleg/150259.pdf.

${ }^{26}$ See Andreu (2008).

${ }^{27}$ Rico (2012), 219-220. Notable exceptions are CCJ 4/1981 and CCJ 247/2007, where the SCC denied the political sovereignty of the autonomous communities. See Casanas Adam (2017), 389-390.

${ }^{28}$ Dowling (2014), 226; Elliot (2018), 239.
} 
Statute's 223 articles, ${ }^{29}$ the political impact of the judgment was severe. ${ }^{30}$ On crucial issues, the SCC overturned the 2006 Statute's central ambitions, striking down provisions enabling Catalonia's fiscal and judicial autonomy. ${ }^{31}$ But perhaps more importantly, by interpreting the 2006 Statute in line with the SC, the SCC puts brackets around the entire symbolical project behind the document. For example, it decided that the Catalan language could not enjoy a preferential status for Catalonia's public bodies. ${ }^{32}$ Also, it insisted that whereas Catalonia may be a "nationality" in an informal sense, it is in no legally relevant sense a "nation": "the Constitution does not recognize anything other than the Spanish Nation." ${ }^{33}$ In other words, formally speaking, the 2006 Statute was largely left intact by the SCC ruling. But effectively, the real intentions behind the document were certainly thwarted. ${ }^{34}$

In the years that followed, the SCC blocked the secessionist agenda several times more. For example, in March 2014, it annulled claims to sovereignty the CP had made in January 2013 and explicitly ruled that Catalonia could not unilaterally hold a "referendum of self-determination." 35 The Spanish central parliament, however, rejected a Catalan request for a bilateral referendum in April 2014. Therefore, the Catalan government (Generalitat) moved to ask the opinion of the people in less official form than a "referendum." It helped set up a "nonreferendum consultation" on November 9, 2014 - or, as it was later strategically framed, a "citizen participation process." ${ }^{36}$ All involvement of the Generalitat in this unofficial plebiscite was later declared illegal by the SCC, ${ }^{37}$ but the "harm" had already been done: of the 2.2 million people who took part in the consultation, more than $80 \%$ voted in favor of secession. Though they lost the popular vote, the separatists in Catalonia won a symbolically crucial parliamentary election in September 2015. The pro-secessionist train became unstoppable, even though the SCC subsequently tried to block every step the Catalans took to independence. Among other things, the Court struck down the CP's "Declaration of the Initiation of the Process of Independence of Catalonia" of November $2015^{38}$ and annulled the Catalan law approving the notorious October self-determination referendum. ${ }^{39}$ Unfortunately, it was too late. A confrontation had become unavoidable.

On October 1, 2017, the self-determination referendum took place in defiance of the SCC's prohibition and resulted in an overwhelming majority in favor of independence. On October 27, after a few weeks of threats back and forth, Catalonia's parliament finally declared independence. That was immediately followed by the Spanish government's invocation of Article 155 of the SC, suspending Catalan autonomy. With the Generalitat and CP being dissolved, new regional elections were necessary, which were again won by the separatists (again without winning the popular vote). Then, after months of political tension and quarrel, Catalonia ultimately managed to install a new government in June 2018, regaining constitutional self-government for the region. In Spain, there also was a change of government. Rajoy's conservative People's Party was replaced as the party of government by Pedro

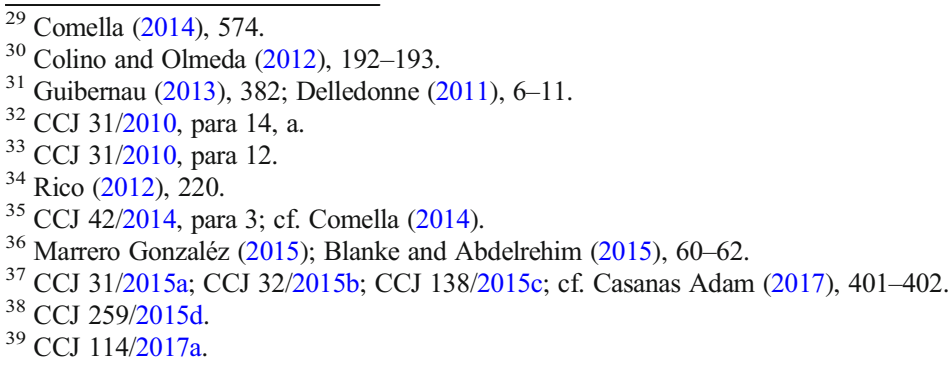


Sánchez's moderate and left-wing Spanish Socialist Workers' Party (PSOE)—incidentally, with the support of Catalan separatists.

In the meantime, as mentioned in Section 1, twelve Catalan political and civil society leaders have been tried and convicted by the Spanish Supreme Court. There is considerable discontent about this among secessionists and about the political "captivity" of Catalonia in Spain more broadly. Consequently, Catalan streets have been the stage to several mass protests, such as on September 11, 2018 (1 mln. people), ${ }^{40}$ October 1, $2019(180,000$ people), ${ }^{41}$ February 16, 2019 (200,000 people), ${ }^{42}$ and on October 18 and 26, 2019 (500,000 and 350,000 protestors). ${ }^{43}$ Using this momentum, Catalan President Quim Torra has gradually tried to intensify the political pressure on Spanish Prime Minister Sánchez. Opportunities may be there now that Sánchez's January 2020 national coalition depends on the Catalan separatists' political support, perhaps allowing the latter to force pro-secessionist concessions. It remains very much to be doubted, however, how far Sánchez will be willing to go. Catalan secessionism is highly unpopular in the Spanish mainland, with the two largest parties behind the PSOE (People's Party and the newly spawned Vox) vehemently rallying against any concessions.

\section{Spanish Law as a Claim to Supreme Authority}

Considering the facts as they have been summarized so far, it seems fair to say that the Catalan crisis has thoroughly escalated over time. Step by step, the SCC became more entrenched in its role to reject Catalan attempts to unilaterally seize more autonomy. And day by day, the Catalan separatists became increasingly allergic to the SCC's intransigent "no." No matter how we evaluate the issue normatively, the SCC has unmistakably become a player in a game that is deeply political. The Court at some point lost its de facto mediating authority and was stuck taking sides in a dispute that cannot be resolved within the logic of the constitution itself. ${ }^{44}$ But perhaps we can give somewhat more theoretical flesh to this observation? What is it that gives courts - and the law they claim to interpret — such a plausible claim to political authority in the first place?

The "service conception" developed by political and legal theorist Joseph Raz offers a useful starting point to examine the concept of political authority. Most importantly, it consists of the so-called normal justification thesis. ${ }^{45}$ Authority is normally justified, Raz asserts, if

the alleged subject is likely better to comply with reasons which apply to him (other than the alleged authoritative directives) if he accepts the directives of the alleged authority as authoritatively binding and tries to follow them, rather than by trying to follow the reasons which apply to him directly. ${ }^{46}$

\footnotetext{
${ }^{40} \mathrm{BBC}(2018)$.

41 Jones (2018).

42 BBC (2019a).

${ }^{43}$ BBC (2019b); Guardian (2019).

${ }^{44}$ Cf. Abat i Ninet (2015), 49.

45 Two other parts are the dependence thesis (Raz 1986, 42-53) and the preemption thesis (Raz 1986, 57-62). The latter shall be dealt with in the next few paragraphs. For the sake of simplicity, I do not treat Raz's dependence thesis in this piece.

${ }^{46} \operatorname{Raz}$ (1986), 53, emph. in orig.
} 
In layman's terms, if it is better to listen to someone or something than not to do so, that person (or thing) is expected to possess legitimate authority. For example, someone who is an expert in the works of Immanuel Kant presumably has special epistemic authority when talking about the Grundlegung zur Metaphysik der Sitten. ${ }^{47}$ Similarly, we might attach special value to the words of our wise grandmother. The grandmother, we might loosely say, is an "authority" to us.

For Raz, however, the genuine exercise of authority requires the presence of another element: the instructions must be "preemptive." That is, the instructions of a genuine authority are not "just another reason," like one advice among others, but exclusionary. Following them means to put aside, or "replace," whatever other reasons one might have that contradict the authoritative statement. ${ }^{48}$ So when a parent exercises authority over his or her child, the child cannot choose to disregard its parent's instructions. Or when a police officer tells you "Stop!," that is not a piece of advice one can freely choose to ignore - even if there is no independent good reason to stop. The reason why is quite straightforward: police officers simply cannot do their job properly unless their instructions are largely abided by. That means that compliance cannot depend on any given individual's assessment of whether there are good reasons to follow the police's instructions. The point in having a police is that they make that choice. ${ }^{49}$

As Raz famously argues, law itself constitutes a claim to authority similar to the police officer's described above. ${ }^{50}$ When a judge convicts a criminal to 20 years in jail, for example, it is not permissible to give him five, or thirty - even if that would strictly speaking have been more just. Relatedly, legal systems claim to be supreme: legal institutions are always supposed to have a higher claim to obedience than other institutions. ${ }^{51} \mathrm{Law}$, the point is, cannot work properly unless its bindingness and priority are not dependent on its content, but rather on the fact that it is law. ${ }^{52}$ Legal reasons therefore necessarily claim to be "protected reasons": they cannot be overturned by considerations of ordinary morality (not, at least, according to legal point of view). ${ }^{53}$ Now, of course, most (if not all) legal systems provide for exceptions to the bindingness of general rules, for example, by allowing for freedom of conscience or acknowledging specific instances of force majeure. ${ }^{54}$ Notice, however, how this fact possibly only strengthens the theory that law constitutes an exclusionary claim: by stipulating what are legitimate grounds for disregarding existing rules, it also implies that non-stipulated grounds are not legitimate. $^{55}$

Time to apply Raz's theory to the Catalan crisis. Can we indeed plausibly understand Spanish law as a claim to the preemptive kind of authority Raz theorizes about? The answer, I think, is evidently "yes." Two constitutional articles have been especially important in the SCC's judgments regarding Catalonia. First, there is Article 1.2 of the SC, stating that

\footnotetext{
${ }^{47}$ Raz distinguishes theoretical from practical authority (i.e., the sort of thing that gives reasons to believe versus the sort of thing that gives reasons to $a c t$ ). The kind of authority studied in this article, political authority, can be considered to be a subset of the latter practical kind of authority and is linked to duties to obey. See Raz (2006), $155-157$.

${ }^{48}$ Raz (1986), 59.

${ }^{49}$ Within their proper authoritative domain, that is. When the authority's competence is clearly exceeded (e.g., without a clear cause, a police officer tells you to remove all your clothes), things change.

${ }^{50} \operatorname{Raz}(1979 b) ; \operatorname{Raz}(1994 a), 215-216$.

${ }^{51}$ Raz (1999), 151-152; Raz (1979c), 118-119.

52 In Hartian-Razian's vocabulary, it aims to provide "content-independent reasons" (Hart 1882, 254-268; Raz 1986, 35-37.

${ }^{53}$ E.g., Raz (1999), 191-193; Raz (1979b), 29.

${ }^{54}$ In technical Razian language, these could be called "cancelling permissions" (see Raz 1979a, 18).

${ }^{55}$ Raz (1979b), 30-31.
} 
"[n]ational sovereignty belongs to the Spanish people, from whom all State powers emanate." ${ }^{, 56}$ According to the SCC, despite everything the CP claims, sovereignty does not belong to Catalonia. ${ }^{57}$ Even more explicitly, in Article 2, the SC states that " $\mathrm{t}$ ] he Constitution is based on the indissoluble unity of the Spanish Nation, the common and indivisible homeland of all Spaniards." As we know from Raz, if the constitution is to have any proper authority, this supreme rule cannot be disregarded. As the SCC put it: "Converting [political projects] into legislation or other manifestations of the public authority's intent is only possible through the procedure for constitutional reform. To do otherwise would be to release the public authorities from any requirement to obey the law, irreparably damaging citizens' freedoms."58

Notice that there are different ways in which the SCC has pushed the separatist-Catalan perspective away from the center of politics. First, there is the Razian point that any legal order must ultimately formally exclude external perspectives from its discourse if it is to have any guiding potential. Let us call this "formal-legal exclusion." That does not necessarily pose a problem: in leaving significant room for self-governing communities, the SC is also crucially accommodating towards wishes for autonomy. ${ }^{59}$ When we notice that the constitutional order's supply of autonomy does not match the demand, however, tensions arise. The Catalan case exemplifies this. Catalan steps to self-government, even if executed through peaceful means, were repeatedly delegitimated by the law and pejoratively called "illegal." We can dub this "substantive-legal exclusion." And then, there is a third way in which the Spanish legal order quells Catalan secessionist ambitions: through the use of repressive public means. Label this "institutional-factual exclusion."

One needs not to look far to see the ways in which institutional repression of the separatist movement is taking place. The Internet is swamped with footage of Spanish order troops hitting peaceful protesters and violently dragging Catalan voters out of polling stations on October 1, 2017. ${ }^{60}$ According to the Generalitat, nearly 900 people were injured in the process. Leaders of the regional police (Mossos d'Esquadra), including chief Josep Lluís Trapero, who failed to cooperate with the violence now face charges of up to 11 years in jail. At the end of October 2017, President Carles Puigdemont left the country in fear of retaliation and fled to Brussels, taking a few of his ministers with him. A few months later, in February 2018, former politician and pro-independence spokeswoman Anna Gabriel also chose exile above prosecution and left for Switzerland, as did member of the CP Marta Rovira in March. Until July 2018, all were subject to an international arrest warrant. In the meantime, prosecutions in Spain have continued. And as mentioned, nine civil and political pro-independence leaders have been put into custody and later imprisoned, thereby not recognizing immunity for elected Member of European Parliament Oriol Junqueras. ${ }^{61}$ Torra and his separatist allies will

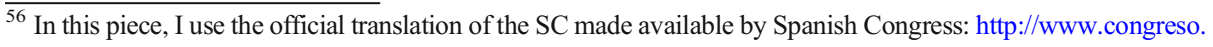
es/portal/page/portal/Congreso/Congreso/Hist_Normas/Norm/const_espa_texto_ingles_0.pdf.

${ }^{57}$ CCJ 31/2010, para 12; CCJ 42/2014, para 3; CCJ 259/2015, para 4a; CCJ $114 / 2017$ a, para 5, 5b; CCJ 124/2017b, para 4.

${ }_{58}^{58}$ CJ 259/2015, para 7.

${ }^{59}$ Part VIII, Chapter 3 of the SC constitutes an elaborate scheme arranging the relation between the Spanish state and the autonomous communities (of which Catalonia is one). Among other things, the autonomous communities have the right to organize their self-governance, to draw the municipal boundaries, and to do spatial planning (art. $148 \mathrm{SC}$ ). The basic principle of regional autonomy can also be found in Article 2 SC: "[The Constitution] recognises and guarantees the right to self-government of the nationalities and regions of which it is composed and the solidarity among them all."

${ }^{60}$ See, e.g., https://www.youtube.com/watch?time_continue=2\&v=GI49YSCruwY (published by Guardian news).

${ }^{61}$ Illegally so the Court of Justice of the European Union ruled (see CJEU December 19, 2019, ECLI:EU:C:2019:1115).
} 
now think twice before they follow the example of their predecessors and embark on the same unilateral path towards independence as their predecessors. Do not mess with Spain's constitutional order, the message is, or it will mess with you.

\section{Mutual Benefit; Law and Democracy}

As we concluded, Raz's framework of law as a claim to preemptive authority is useful in conceptualizing the repressive attitude of Spanish political institutions towards separatist Catalonia. If we really want to understand what happened in those thrilling months in 2017, however, a more rigorous analysis is required. After all, to say that the SCC's claims to have the authority to exclude Catalan appeals to independence from the public domain is one thing. But the fact that this claim is generally deemed plausible and acted upon is quite another. Surely the SCC (and those enforcement troops acting on its rulings) does not take themselves to be exercising mere coercive force over an unwilling Catalan population. As Raz's normal justification thesis shows, an intelligible reconstruction of Spanish de facto authority involves an attempt to grasp the reasons underpinning its claim to obedience. I discuss three such candidate reasons. The first two of these (the "mutual benefit argument" and the "law and democracy argument") are considered in this section, the third ("law and order argument") in the next.

To start with the mutual benefit argument: it would simply be very bad for all parties involved if Catalonia separated from Spain. Bad for Spain, bad for Europe at large. And bad for Catalonia itself, too, especially if you consider the fact that it will be hard to leave Spain and still remain in the EU. Tariffs and physical borders would block trade and economic prosperity. Big businesses would leave the Barcelona metropolis. Catalonia would have to build an expensive state infrastructure with embassies, a central bank, and so forth. And "independent Catalonia would have to create its own currency with a devaluation between 30 percent and 50 percent; its GDP [gross domestic product] would be reduced by between 25 percent and 30 percent," former Economy Minister Luis de Guindos adds. "[That] is so irrational that Europe does not see it as a viable scenario and the government of Spain will not allow this to happen." 62

Could this essentially prudential line of argument underpin a Catalan duty to acknowledge the SCC's judgment as authoritative? I doubt it. Remember that the argument in favor of the SCC's authority cannot rest on considerations about the content of the decision itself - that would violate the principle that authority binds content independently. Rather, it must be an argument claiming that the SCC generally produces good judgments on this sort of issues and that that fact in itself generates a duty to obey. As far as this concerns protecting Catalonia's own interests, that is not very convincing. A right to self-rule, which separatist Catalans seem to believe in, usually also involves a right to reach irresponsible decisions ${ }^{63}$ Besides, if leaving Spain would be a bad idea because Spain refuses to make proper trade agreements and pressures the EU not to allow Catalonia to enter, whose fault is that, really? Admittedly, to the extent that the mutual benefit argument stems from a concern for Spanish interests, the issue becomes more difficult. Indeed, perhaps there is a moral duty for Catalans to take care of their less wealthy Spanish brothers. The question remains, however, whether the moral force

\footnotetext{
${ }^{62}$ Saeed (2017).

${ }^{63}$ Cf. Margalit and Raz (1990), 454.
} 
of this argument is properly captured in terms of Spanish benefit. Suppose, for example, that it would be good for Belgians if Luxembourg would become part of Belgium and that Belgian authorities are particularly competent in establishing this. Surely that would not entail a Luxembourgian obligation to obey Belgian authorities if they would declare Luxembourg to be a part of Belgium. Apparently, we need more than mere "benefit" to explain the alleged Catalan duties to obey Spanish authority.

For these reasons, those who favor the SCC's point of view have another argument in store: the aforementioned "law and democracy argument." The Catalan decision to secede, the idea is, was not a genuinely democratic decision, because it did not match the basic rules that are to be expected in a liberal democracy. Democracy does not exist in a vacuum. It needs to be given shape and empowered through a constitutional framework of legally mandated public institutions. ${ }^{64}$ According to Article $168 \mathrm{SC}$, the union of Spain can only be broken by two consecutive two-thirds majority votes in both houses of parliament, and a subsequent referendum. The Catalan separatists are perfectly allowed to pursue such a majority in national parliament, and yet, they failed to do so. ${ }^{65}$ What is more, the majority of the separatists in the CP in 2017 were only small, 72 out of 135 seats in parliament. Should there not be a larger majority for such an important decision as a declaration of independence-especially considering the aforementioned fact that the separatists did not even win the popular vote? The independence referendum law of September 2017 was rushed through virtually without prior notice, after a debate that lasted less than half a day. Perhaps even more problematically, the separatist majority refused to wait for an advisory opinion from the Council of Statutory Guarantees, even though the opposition was entitled to that opinion, ${ }^{66}$ entitled by Catalan statutory law, by the way, not by Spanish law, ${ }^{67}$ and then the independence referendum itself. Admittedly, almost $90 \%$ of the voters voted pro leave, but how reliable is such a result if most "remain" voters do not acknowledge the referendum's legitimacy (and therefore presumably stayed at home)?

Those are all powerful and arguably insurmountable criticisms of the way the pro-secession politicians in Catalonia organized their campaign. "We want to talk, as well established democracies do," Puigdemont wrote on October 16, 2017 in a letter to his colleague Rajoy. ${ }^{68}$ But why is Puigdemont then so clearly violating democratic principles himself? That is a question well worth asking. Still, we must be careful not to conflate the claim that the Puigdemont administration acted undemocratically with the claim that the SCC's judgments carry democratic authority. Most certainly, the events of September and October 2017 are no showcases of healthy democratic procedure, but do Spain's national institutions go off the hook there? First of all, in a banal sense, it is hard to organize an orderly and successful referendum if Spanish law enforcement crushes in, walking around seizing ballot boxes and beating voters. More fundamentally, Catalan secessionist resentment is not likely to have

\footnotetext{
${ }^{64}$ Cf. the speech from the Spanish King Felipe VI: "[A]s we all know, without respect for the law, there is no possible democratic coexistence in peace and freedom, neither in Catalonia, nor in the rest of Spain, nor anywhere in the world" (El 2017). Felipe's words echo Habermasian notions of the co-originality (gleichursprünglich[keit]) of legal code and democratic principle (Habermas 1994 [1992], 155) and are also interestingly reflected in the Canadian judgment on the secession of Quebec (Canada Supreme Court 1998, 2 SCR 217, para 67, 78).

${ }^{65}$ CCJ 42/2014, para 4c; CCJ 114/2017a, para 5c.

${ }^{66}$ See CCJ 114/2017a (para 5b-5d) for an overview of all the procedural missteps made in the months leading to the September 2017 independence referendum.

${ }^{67}$ See Article 76 of the 2006 Statute.

${ }^{68}$ Shared on https://twitter.com/catalangov/status/919864470092046341?s=09.
} 
arisen out of thin air. If you assume a principle of democratic self-rule, and consider the fact that separatists have consistently called for more autonomy, feelings of resentment are hardly surprising. The three Spanish powers of government - not only the SCC, but also the government and parliament — have hardly done anything else than simply to deny all requests. Indeed, a minority position as it is in Spain, Catalan separatism is likely never to gain support in two consecutive two-third majority votes in Spanish parliament in the foreseeable future. In such a case, it seems a principled attitude of non-accommodation fails to meet the normative requirements of democracy. ${ }^{69}$ Democracy, to be sure, means more than mere majority rule. ${ }^{70}$

Now, importantly, that all is not to say that the mutual benefit argument and the law and democracy argument are not grounded in normatively significant insights. Indeed, someone who is already disposed to view the SCC's authority as legitimate may very well be strengthened in that disposition by considering mutual benefit or democracy-based arguments. Such a person may still occasionally choose to reject Spanish legal authority in particular instances, but is then likely to experience moral loss, flowing from the existence of a loyalty conflict. $^{71}$ Remember, however, that this article only has a limited ambition: to review the SCC's authority claims from the perspective of someone who does not take its legitimacy for granted. From that point of view, my point is, the mutual benefit and democracy arguments will not look very satisfying. To put it more precisely, they do not present any second-order reasons to accept the SCC's supreme authority — at least not independently. When fundamental questions of political identity are at stake, the mutual benefit argument seems too technocratic to persuade. Similarly, the law and democracy argument is not very likely to play the required mediating role. The SCC's reasoning is essentially circular: if one accepts Spanish constitutional amendment as the only legitimate procedure to achieve more Catalan political autonomy, all other steps are illegal. But that circularity seems problematic. The dispute arises, after all, precisely due to a disagreement on the sovereignty question. The separatist Catalans could presumably at least temporarily have been contented with a referendum, such as organized in the UK for Scotland in 2014 (or regarding Brexit in 2016). But for both the SCC and the Spanish parliament, that demand evidently went a bridge too far.

\section{The Law and Order Argument}

To repeat, this all does not imply that the mutual benefit and democratic arguments are unreasonable, let alone that it would be a good idea for Catalonia to split off from Spain. We can stay agnostic regarding those matters and still establish that the benefit-based and democratic arguments are incapable to independently validate the SCC's claim to authority. As I argue below, however, a version of the third "law and order argument" can be a valid argument, especially when it comes to legitimating the role the SCC has played. This section unpacks this law and order argument a little bit further.

\footnotetext{
${ }^{69}$ In the Canadian Quebec secession judgment, this element of democratic accommodation is insightfully fleshed out by reference to an "obligation to negotiate" (Canada Supreme Court 1998, 2 SCR 217, para 88-104). This is undoubtedly an important principle regulating the Catalan context as well, which makes Spanish politicians' consistent refusals to negotiate remarkable in light of Catalonia's often repeated requests to talk.

${ }^{70}$ Cf. Van der Burg 1989, 297.

${ }^{71}$ An example is perhaps found in the Catalan police officers who-moved to tears by the tragedy of the situation - on October 1, 2017 chose to protect Catalan voters and protesters against violent Spanish enforcement troops. See https://www.youtube.com/watch?v=rfnlbRBWBCw for some famous images.
} 
As the name already indicates, the law and order argument puts special focus on the importance of values like stability and legal certainty. Though these may of course be considered just some political values among others, when functioning as the basis for an authority claim, the law and order argument usually appears as a meta-argument. No matter one's political agenda or political-philosophical views, the idea is, in some cases, we are fundamentally not in the position to reject the legitimacy of existing political arrangements. Unlike with the mutual benefit argument, however, the reason is not that those specific political arrangements necessarily make our lives better. Rather, it is because we have no choice but to rely on them-even if we would rather live in a world without our current political institutions, now they are here, we do better to recognize their authority. That also signifies what distinguishes the law and order argument from the law and democracy argument discussed in the previous section. Whereas the latter tries to ground political obligation in abstract ideals of democratic representation, the former focuses on the de facto normative order that we encounter in our daily lives. Though it is true we did not precisely choose what political institutions (e.g., the Kingdom of Spain) are currently in place, the bare fact of their existence carries undeniable moral relevance. ${ }^{72}$

Cut to its core, the law and order argument starts with a rejection of the philosophical anthropology of the political consumer as the center of the universe. Political life is not like a trip to the shopping mall, where one can freely roam about and choose to buy the products one happens to find an attractive supplement to what one already owns. Rather, it is like doing your shopping while simultaneously being responsible for the general maintenance of the mall and all the stores in it. Or to use Michael Oakeshott's famous metaphor, it is like navigating a ship: one cannot do it without first making sure that the vessel keeps afloat. ${ }^{73}$ Keeping afloat the existing system of government under the law, then, is something we are all responsible for, even if the ultimate foundations of that system are perhaps morally contingent and arbitrary. The reason is, quite simply, that the stability that existing law provides is something way too important to put on the line. On the one hand, law allows us to peacefully resolve disputes and coordinate collective plans, ${ }^{74}$ uniting a diverse set of individuals under a common set of legal procedures. On the other hand, due to this procedural nature, law can help us to much more effectively monitor and constrain the exercise of collective action. It is a kind of societal pact - a contract, if you will. Legal institutions, such as courts, governments, and parliaments, are not allowed to exceed the powers vested in them by historically created law and constitution. In return, they get to ask compliance from citizens and subordinate institutions. It seems that the kind of respect for legality inherent in this reciprocal bond is implicit in any credible notion of the rule of law. ${ }^{75}$

The important takeaway point here is that the rule of law is not a random artifact that exists independently of our actions. It is actually an enormous social achievement, generated by a collective commitment to fidelity to law. This commitment to legality, we must realize, becomes little more than incoherent folly if it is conditional on the accidental alignment of

\footnotetext{
72 The argument to be presented in this section echoes the Rawlsian idea that there is a general "duty to uphold and to further just institutions" (Rawls 1999 [1971], 257-258). Probably even more strikingly, it resembles Jeremy Waldron's interpretation of Henry Hart and Albert Sacks' "principle of institutional settlement." See Waldron (2003), 69: "[E]ach citizen must be prepared to swallow hard and submit his own sense of what the best option might be in order to join in with group coordination on some option even if it is not the best."

${ }^{73}$ Oakeshott (1962), 127.

${ }^{74}$ Shapiro (2011), chpt. 6.

${ }^{75}$ Fuller (1969 [1964]), 39-41.
} 
the law's perspective with our own. That is the basic Hobbesian axiom: social order is something inherently worth protecting, because it is both too important and too fragile simply to take for granted. Asking why the Catalans should not try to unilaterally secede, one could say by analogy, is a bit like asking why we should not take someone else's property without permission. The reason is not that the current scheme of property distribution (or political sovereignty distribution, for that matter) is in some way maximally just or maximally democratic. Rather, the point is that political order necessarily relies on certain historically grown rights and entitlements, generating stability and legitimate expectations. Indeed, even if there is no good reason of ahistorical justice that I have much more money than you, you are still not permitted to go ahead and steal my car. ${ }^{76}$ Similarly, there might be no principle of ahistorical justice justifying that Catalonia is part of Spain. But still, there may be a relative wrong in unilaterally breaking the bond of sovereignty and seizing territory in order to create a

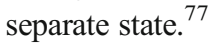

There is quite something at stake here. Notably, the notion of the "indissoluble unity of the Spanish Nation" (Art. 2 SC) is there for a reason. Yes, perhaps Spain as it is is not perfect, but at least it is - and building on institutions that are is a necessary precondition for political order. Suppose the SCC would recognize an "inalienable right to self-government" to any political entity claiming to be independent. ${ }^{78}$ Or, even worse, imagine that the SCC would have backed down and approved of the CP's claims to sovereignty and independence after it already ruled its 2010 judgment. What would that mean for the nation's political stability? Separatist Catalans may want a diplomatic relationship with Spain as coequals, maintaining stable forms of economic and political cooperation. Such a wish is hardly coherent, however, if Spain is to be shred apart by calls for autonomy everywhere, such as in Galicia, the Basque Country, and other regions. ${ }^{79}$ An independent Catalonia might desire to join the EU, but would that mean the regions of Flanders, Bavaria, and Padania should have the same right? ${ }^{80}$ Quite surely, the line must be drawn somewhere if a governable political constellation is to remain operative at all. Besides, would separatist Catalans be evenly tolerant to claims to selfgovernment if, say, the Catalan city of Girona would want to split off in its own right?

With the law and order argument, it finally appears there is an inherent reason to abide by the SCC's judgments that even Catalan secessionists cannot decline to (at least) take seriously. Moreover, it can ground the moral force of the arguments named in the previous section. There, we concluded that the mutual benefit argument in itself does not justify the Spanish position, because the court has no special legitimacy in deciding on policy questions. And we rejected the law and democracy argument as a legitimation of the Spanish repression, because referring to existing constitutional arrangements does not justify the constitution itself. But viewed against the background of the law and order argument, the burden of proof is shifted. Why should we buy into utopian promises of a prosperous Catalan state if we currently have

\footnotetext{
${ }^{76}$ According to Robert Nozick, this historicity is even a principled element of theories of justice (Nozick 1974, 150-182). I am inclined to agree, but for the purposes of this piece, an instrumental grounding suffices.

77 The territorial principle is one of the most powerful arguments in anti-secessionist theory's arsenal: secession requires the taking away of land, which seems an act that by itself must be separately justified (Brilmayer 1991, 187-189; Buchanan 1991, 328. Disagreeing: Copp 1997, 281-282; Altman and Wellman 2009, 46).

${ }^{78} \mathrm{Cf}$. the Preambule to the 2006 Statute.

${ }^{79}$ Basque secessionism is alive and well; certainly now, Catalan separatism is thriving. Galician nationalism so far usually does not take a secessionist form, although the pro-independence movement there has also been emerging. See Warf and Ferras (2015), 264-265.

${ }^{80}$ As Jean-Claude Juncker put it, "[i]f we allow Catalonia to separate, others will do the same ... I would not like a European Union in 15 years that consists of some 98 states." See Reuters (2017).
} 
Spanish institutions, which at the moment appear to function comparatively well? Is that really something we want to put at risk? Democracies, we must remember, can only be consolidated if all parts are loyal to the whole, genuinely participating in common deliberations without threatening to shred it apart. ${ }^{81}$

Now, to be clear, this all still does not necessarily mean that Catalan secessionism becomes an untenable position once one accepts the normative cogency of law and order considerations. Catalan separatists will obviously dispute the purported self-evidence of the existing Spanish order and rally for a reinterpretation of history to the effect of establishing that sovereignty lies with Catalonia. ${ }^{82}$ When the discussion reaches that stage, it becomes a matter of word against word — or, more accurately, narrative against narrative: who has the rightful claim to legal authority here? In the ideological quarrel that follows, few measures are off limits, and much will be decided by (rhetorical and other) force. The reason is basically Darwinian and can readily be deduced from the previous paragraphs. If a political project is to subsist, it cannot be tolerant towards hostile forms of organizations that seek to lay its core normative underpinnings to waste. That is where the political rubber hits the road: once a law and order claim is successful, other political concerns are displaced and pushed to the background.

Remember, to avoid confusions, that the fact that a de facto political authority demands uncompromised attitudes of obedience does not necessarily mean that that demand will be accepted. Yes, Spanish unionist will claim that there are content-independent reasons to accept the SCC's authority no matter what, but Catalan secessionists have reason to be unpersuaded. They might point out, for example, that the SCC is unduly biased in favor of the status quo and argue that its law and order claim illegitimately declares a constitutional state of emergency. From the more detached perspective of the analyst, we may summarize that constitutional crises like the one in Catalonia in 2017 are moments when two opposing logics of the public sphere meet. On the one hand, there is the thing Jacques Rancière would call "police," 83 which concerns the need to uphold constitutional order. On the other hand, there more rare moments of what one might call constitutive moments, or "politics" proper: "whatever breaks the tangible configuration whereby parties ... are defined." 84

The Catalan bid for independence could well be understood as an attempt to open the political space, to make a political demand as to reform the existing police logic. That is to say, it is an attempt to question the boundaries of the public sphere, presenting a new constitutional logic as an alternative to the old one. At that moment, the SCC was forced to make a political choice: exclude the new constitutional claim (and maintain old law) or accommodate it (and thus redraw constitutional boundaries). Needless to say, the Court ultimately chose the first option and thus claimed restorative police power in the face of the political. Now, the point is

\footnotetext{
${ }^{81}$ Sunstein (1991), 648-652. Notice that the law and order argument's sensitivity for historically grown entitlements does not preclude a certain political pragmatism (on the contrary). Someone who denied the legitimacy of an independent Israel in 1948 can coherently face the facts and acknowledge Israel's statehood a few decades later. The same counts for declarations of independence generally: realism may force one to accept even what one resisted initially.

${ }^{82}$ Striking, in this regard, is the Catalan declaration of independence, which appeals to the "legal and institutional traditions of Catalonia." "The Catalan nation, its language and culture," the document emphasizes, "have a thousand years of history. For centuries, Catalonia has maintained and run its own institutions in complete selfgovernance." See http:/www.cataloniavotes.eu/wp-content/uploads/2017/10/27-Declaration-ofIndependence.pdf for an English translation of the declaration.

83 Rancière (2006), 299.

${ }^{84}$ Rancière (1999 [1995]), 29.
} 
not that the SCC could not or should not have done differently-indeed, there is no clear reason why the Court could not have drawn the line in a more accommodative fashion. Rather, the point is that the Court did not do differently. Once the Court had chosen to construe the SC in a more exclusive manner, there was no way back. The result was a split, a rupture. With the judgment of the SCC, the Spanish high priest had spoken: get back in line, or be an outlaw.

Notice how there is a sense in which this is quite different from how courts ordinarily function. Under the Razian model, judicial authority normally flows from a sense of constitutional dignity. We accept the judgments of courts because their conduct is governed by the glue of a shared legal procedures and standards. ${ }^{85}$ But it is precisely this sense of constitutional glue or sharedness that is at stake in crises like the Catalan one. ${ }^{86}$ The SC's and SCC's constitutional authority is no longer assumed, as in normal circumstances of legality, but rather asserted. That is what it means to truly exercise constitutional sovereignty in a Schmittian sense: "determining definitively what constitutes public order and security." 87

\section{Conclusion: Rethinking the Concept of Authority}

One of the major perks of the Razian framework of authority is its power to conceptualize reasons people may have to accept the existence of a duty to obey specific authoritative claims. The theories of philosophical anarchists like Robert Paul Wolf and Hobbesians like Robert Ladenson are less suitable there. By denying that there is such a thing as legitimate authority, ${ }^{88}$ or by denying that authority is linked to duty, ${ }^{89}$ they fail to explain the phenomenology of juridico-political life. As Raz rightly observes, authority is more than a right to knock people over and exercise coercion, thereby treating them as mad dogs that need conditioning. Rather, to exercise authority is to ascribe $d u t y$ - a moral expectation that one is to be obeyed. ${ }^{90}$ Hence follows an important methodological axiom that has also underlain this article's design. If we want to fully explicate how a de facto authority (like the SCC) appeals to its subjects, we need to look into the reasons we might have to acknowledge a duty to obey that authority.

In the general literature on authority, some doubts have been raised whether Raz's own framework can actually do the job of explaining the existence of duties to obey. According to Raz's aforementioned normal justification thesis, authority derives from "service": a potential to better the conditions of subjects as individuals in acting on their reasons. As critics have noted in response, however, the foundations of political authority often rather seem collectively-procedural and distinctively relational. The rights of a ruling institution, for example, are not merely determined by the quality of its decision making, but also by its democratic

\footnotetext{
${ }^{85}$ Cf. Raz (1986), 72.

86 The matter is even further complicated here by the notion that there can never be a duty to respect the law qua law without a certain kind of (semi-)voluntary commitment. See Raz (1994b).

87 Schmitt (1985), 9.

88 Wolf (1970).

${ }^{89}$ Ladenson (1990).

${ }^{90}$ Admittedly, there can be doubts whether this inherent link between political authority and duty is always there. As Steve Coyne notes, "it strains credulity to suggest one could be obliged to walk themselves to the gallows" (though it certainly seems an exercise of authority to send someone to the gallows; see Coyne 2016, 581). Whatever we think of Coyne's example, we can assume these kinds of circumstances are quite exceptional. For example, there does seem to be a general obligation to pay justly imposed fines, or to show up for community service.
} 
legitimacy. ${ }^{91}$ And the rights of, say, a parent vis-à-vis his or her child are distinctive for the parent-child relation, as only parents can exercise the rights of parental authority. ${ }^{92}$ Both these procedural and relational objections essentially boil down to the same point. To recognize that it would be better to accept someone or something as an authority does not establish that person or thing actually is an authority. Even if another person would perhaps be a better parent for you, what usually counts is that it is simply not your parent. Similarly, even if I could compose adjudicative panels that would produce better judgments than the courts actually present, what matters is that those other courts are simply not legally assigned courts. ${ }^{93}$

I would like to suggest that this tells us a lot about the moral texture of the Spanish-Catalan constitutional conflict. As we saw in Section 4, the mutual benefit argument does not suffice as a foundation for the SCC's authority. The reason coincides with the general point spelled out in the previous paragraph: simple benefit (or "betterness") cannot establish a proper moral bond of political duty. A somewhat different and yet related problem appeared with the law and democracy argument. To be sure, we might agree about the importance of ideals of legality and democracy, but the question what legality and whose democracy cannot be resolved on an abstract level. That is why Section 5 had to add a necessary supplement: the law and order argument. It provides a rational basis for what at first might look like a naturalistic fallacy: things are as they are, so let us keep them this way. Notice the paradox, however. Although any law and order claim must be grounded in an already valid set of constitutional documents or practices (the historical-relational element), strictly speaking, it never can be. After all, if a constitutional order were already considered to be the legitimate authority prior to any intervention, there would be no need to assert legitimacy. Apparently, in times of crisis, the authority of institutions in moments of crisis is self-constitutive: "Order is hereby restored, don't jeopardize this achievement by disobeying!" Notice the phrasing here: order is restored. Once the authority claim successfully made, it is ipso facto already validated as a social reality. Who gets to successfully make these kinds of law and order claims can perhaps sometimes be predicted, but only legitimated after the claim has been made. The reason is that the intersubjective room in which this extraordinary form of authority exercise functions is not one of prior moral legitimation, but rather one of undeniable social presence. ${ }^{94}$

So what is the upshot of all this for ordinary cases - circumstances under which the authority of our legal institutions is not put under existential question? Sure, there are always rare moments when constituted powers (like courts) become the object of constitutional controversy, temporarily making their political foundations unstable. Just like human beings become ill once in a while, legal systems have their pathologies, but are the moments of lack of pathology not much more telling? ${ }^{95}$ Usually, we do not see the claims of constitutional agents (such as courts) as explicit claims to political authority. Rather, we experience their authority as part of the natural furniture of society. Still, the fact that political authority does not always

\footnotetext{
${ }^{91}$ Besson (2005); Christiano (2008); Hershovitz (2003, 2011).

92 Himma (2007); Darwall (2013a, b); Adams (2018).

${ }^{93}$ I am aware that defenders of Raz's service conception have ways to try and incorporate these critiques (e.g., Raz 2010; Enoch 2014). I do not wish to dispute the formal validity of those defenses here but just intend to filter out the basic moral-phenomenological insights behind the criticisms of Raz's model.

${ }^{94}$ This is again a Schmittian idea: the exercise of authority in the exceptional case cannot be bound by any prior legalistic or moralistic logic, because by its very nature defines that logic (see Schmitt 1985, 12-13).

${ }^{95}$ Cf. Hart 1994[1961] on moments of constitutional crisis: "All we could do would be to describe the situation ... and note it as a substandard, abnormal case" (123). Schmitt (1985) represents the opposite position: "The rule proves nothing, the exception proves everything" (15).
} 
have to be asserted explicitly does not mean that the continuous exercise of constitutive power is not there implicitly. Although commonly hidden beneath the moralized surface of a constitutional order, there always remains a decisionistic element of self-assertion in every authoritative judgment. Strictly speaking, even the technical case law produced by a lower administrative court could be seen as a reaffirmation of embedded hierarchies: "Order is hereby maintained, don't jeopardize this achievement by disobeying!"

This leads me to leave a final note about the structure of the scholarly debate about authority. Produced largely in response to the anarchist's challenge, perhaps contemporary attempts to understand the concept of authority got off on the wrong foot. Analyses of authority like Raz's depart from what one could call a hypothetical non-existence test: would it be better if de facto authority $\mathrm{X}$ were not there? I would contend that there is quite a misleading account of political judgment implicit here. Usually, the choice is not between $\mathrm{X}$ and $\neg \mathrm{X}$ (e.g., having a dictator or not having a dictator), but rather between $\mathrm{X}$ and $\mathrm{Y}$ (e.g., supporting the dictator or supporting the countermovement). In the latter situation, the hypothetical non-existence test does not work. Instead, one needs an a posteriori contextual judgment: given all the claims to loyalty imposed on us, whom do we owe our fidelity to? Crucially, in such a circumstance, an assessment of the legitimacy (i.e., support-worthiness) of a claim to authority cannot be abstracted from the existence of the claim itself. We might not like, say, the composition of the US constitution, but since it is there, we better work with what we have. Similarly, we might not like the SCC's judgment, but since it is there, it is impossible to ignore. That is the basic lesson from decisionism. Sure, de facto authorities may be critically evaluated as to make them responsive to reason, but at the same time, they constitute the very terms in which those evaluations will take place. We are, to put it in Bonnie Honig's terms, always between decision and deliberation. ${ }^{96}$

Open Access This article is licensed under a Creative Commons Attribution 4.0 International License, which permits use, sharing, adaptation, distribution and reproduction in any medium or format, as long as you give appropriate credit to the original author(s) and the source, provide a link to the Creative Commons licence, and indicate if changes were made. The images or other third party material in this article are included in the article's Creative Commons licence, unless indicated otherwise in a credit line to the material. If material is not included in the article's Creative Commons licence and your intended use is not permitted by statutory regulation or exceeds the permitted use, you will need to obtain permission directly from the copyright holder. To view a copy of this licence, visit http://creativecommons.org/licenses/by/4.0/.

\section{References}

\section{Official Legal Opinions and Court Judgments}

Canada Supreme Court (1998) 2 SCR 217 (20 August - Reference Re Secession of Quebec)

Court of Justice of the European Union (2019), ECLI:EU:C:2019:1115 (Junqueras Vies)

Human Rights Commission (2019) A/HRC/WGAD/2019/6

Spanish Constitutional Court Judgment, (1981)No. 4/1981 (February 2)

Spanish Constitutional Court Judgment (2007) No. 247/2007 (June 28)

Spanish Constitutional Court Judgment, (2010) No. 31/2010 (June 28). For an English translation: https://www. tribunalconstitucional.es/ResolucionesTraducidas/31-2010,\%20of\%20June\%2028.pdf. Accessed 6 Sept 2020

\footnotetext{
${ }^{96}$ Honig (2007).
} 
Spanish Constitutional Court Judgment, (2014) No. 42/2014 (March 25). For an English translation: https:/www.tribunalconstitucional.es/ResolucionesTraducidas/STC\%2042-2014E(2)\%20\%20 DECLARACION\%20SOBERANISTA\%20\%20SIN\%20ANTECEDENTES.pdf. Accessed 6 Sept 2020

Spanish Constitutional Court Judgment, (2015a) No. 31/2015 (25 February)

Spanish Constitutional Court Judgment, (2015b) No. 32/2015 (25 February)

Spanish Constitutional Court Judgment, (2015c) No. 138/2015 (11 June)

Spanish Constitutional Court Judgment (2015d)No. 259/2015 (2 December). For an English translation: https:/www.tribunalconstitucional.es/ResolucionesTraducidas/STC\%20259\%20-\%202015\%20\%209N\%20 (English).pdf. Accessed 6 Sept 2020

Spanish Constitutional Court Judgment (2017a) No. 114/2017 (17 October). For an English translation: https:/www.tribunalconstitucional.es/NotasDePrensaDocumentos/NP_2017_074/JUDGMENT\%2020174334STC_EN.pdf. Accessed 6 Sept 2020

Spanish Constitutional Court Judgment, (2017b) No. 124/2017 (8 November). For an English translation: https://www.tribunalconstitucional.es/ResolucionesTraducidas/Ley\%20transitoriedad\%20ENGLISH.pdf. Accessed 6 Sept 2020

Spanish Supreme Court Judgment, (2019) No. 459/2019. Causa Especial 20907/2017 (14 October)

\section{Literature, News Articles, and Reports}

Abat i Ninet A (2015) The Spanish constitution, the constitutional court, and the Catalan referendum. In: Nagel KJ, Rixen S (eds) Catalonia in Spain and Europe: is there a way to independence? Nomos Verlagsgesellschaft, Baden-Baden, pp 42-51

Adams MP (2018) The relational conception of practical authority. Law Philos 37:549-575. https://doi. org/10.1007/s10982-017-9323-3

Altman A, Wellman CH (2009) A liberal theory of international justice. Oxford University Press, New York

Amnesty International (2018) A year after their detention in Spain, the Jordis should be released. 16 October. Available at: https://www.amnesty.org/en/latest/news/2018/10/spain-a-year-after-their-detention-the-jordisshould-be-released. Accessed 6 Sept 2020

Amnesty International (2019a) SPAIN: authorities must de-escalate tensions and guarantee the right to public assembly. 18 October. Available at: https://www.amnesty.org/en/latest/news/2019/10/spain-authoritiesmust-deescalate-tensions-and-guarantee-the-right-to-public-assembly/. Accessed 6 Sept 2020

Amnesty International (2019b) Spain: analysis of the Supreme Court's ruling in the case of Catalan leaders. EUR 41/1393/2019. Available at https:/www.amnesty.org/download/Documents/EUR4113932019ENGLISH. PDF. Accessed 6 Sept 2020

Andreu JMC (2008) Spanish autonomic state reform: Catalonia's 2006 new statute of autonomy. Senshu Hogaku Ronshu (The Journal of Law and Political Science) 102:89-137

BBC (2018) Catalonia 'National day' rally draws million. 12 September. Available at https://www.bbc. com/news/world-europe-45492205. Accessed 6 Sept 2020

BBC (2019a) Catalan separatists stage mass protests in Barcelona. 16 February. Available at: https://www.bbc. com/news/world-europe-47268020. Accessed 6 Sept 2020

BBC (2019b) Catalonia protests: marches and general strike paralyse Barcelona. 18 October. Available at: https://www.bbc.com/news/world-europe-50098268. Accessed 6 Sept 2020

Besson S (2005) Review article: democracy, law and authority. J Moral Philos 2(1):89-99. https://doi. org/10.1177/1740468105052585

Blanke HJ, Abdelrehim Y (2015) Catalonia's independence - is there a way in international and European Union law? In: Nagel KJ, Rixen S (eds) Catalonia in Spain and Europe: is there a way to Independence? Nomos Verlagsgesellschaft, Baden-Baden, pp 52-97

Bosch A (2013) Judo in Madrid. In: Castro L (ed) What's up with Catalonia? The causes which impel them to the separation. Catalonia Press, Ashfield, pp 113-118

Brilmayer L (1991) Secession and self-determination: a territorial interpretation. Faculty scholarship series, paper 2434

Buchanan A (1991) Toward a theory of secession. Ethics 101(2):322-342

Buchanan A (1997) Theories of secession. Philos Public Aff 26(1):31-61

Cabanas A (2019) Spain isn't imposing excessive punishment on Catalonia's leaders. It's enforcing the law. Foreign Policy, 14 November 2019. Available at: https://foreignpolicy.com/2019/11/14/spain-isntimposing-excessive-punishment-on-catalonias-leaders-its-enforcing-the-law/. Accessed 6 Sept 2020

Cardús S (2013) What has happened to us Catalans? In: Castro L (ed) What's up with Catalonia? The causes which impel them to the separation. Catalonia Press, Ashfield, pp 95-100 
Casanas Adam E (2017) The constitutional court of Spain: from system balancer to polarizing centralist. In: Aroney N, Kincaid J (eds) Courts in federal countries: federalists or unitarists? University of Toronto Press, Toronto and Buffaloand London, pp 367-403

CatalanNews (2019) Amnesty: referendum leaders' verdict is 'against human rights international law'. 19 November. Available at: https://www.catalannews.com/catalan-trial/item/amnesty-referendum-leadersverdict-is-against-human-rights-international-law. Accessed 6 Sept 2020

CEO/Centre d'Estudis d'Opinió (2013) Baròmetre d'Opinió Política. 3a onada 2013

CEO/Centre d'Estudis d'Opinió (2020) Baròmetre d'Opinió Política. 2a onada 2020: Taules estadístiques

Christiano T (2008) The authority of democracy. In: The constitution of equality: democratic authority and its limits. Oxford University Press, New York, pp 231-259

Colino C, Olmeda JA (2012) The limits of the flexibility for constitutional change and the uses of sub-national constitutional space: the case of Spain. In: Benz A, Knüpling F (eds) Changing federal constitutions: lessons from international comparison. Barbara Budrich, Opladen, pp 191-209

Comella VF (2014) The Spanish constitutional court confronts Catalonia's 'right to decide' (comment on the judgment 42/2014). Eur Const Law Rev 10(3):571-590

Commissioner for Human Rights (2019) Protection of the rights to freedom of expression and peaceful assembly during last week's demonstrations in Catalonia. Council of Europe Portal, 21 October. Available at: https://www.coe.int/en/web/commissioner/-/protection-of-the-rights-to-freedom-of-expression-andpeaceful-assembly-during-last-week-s-demonstrations-in-catalonia. Accessed 6 Sept 2020

Copp D (1997) Democracy and communal self-determination. In: Mckim R, McMahan J (eds) The morality of nationalism. Oxford University Press, New York/Oxford, pp 277-300

Copp D (1998) International law and morality in the theory of secession. J Ethics 2(3):219-245

Coufalová L (2017) Lost credibility: who should be blamed for the increasing support for separatism in Catalonia? Politologická Revue (Czech Political Science Review) 23(1):133-159

Coyne S (2016) Coercion and obligation as exercises of authority. Jurisprudence 7(3):575-592. https://doi. org/10.1080/20403313.2016.1236895

Darwall S (2013a) Authority and second-personal reasons for acting. In: Morality, Authority, and Law: Essays in Second-Personal Ethics I. Oxford University Press, Oxford, pp 135-150

Darwall S (2013b) Authority and reasons: exclusionary and second personal. In: Morality, Authority, and Law: Essays in Second-Personal Ethics I. Oxford University Press, Oxford, pp 151-167

de Síndic de Greuges Catalunya (2018) The violation of fundamental rights and freedoms arising from the criminal justice reaction following October 1, and application of Article 155 of the Spanish Constitution. Available at: http://www.sindic.cat/site/unitFiles/5324/Report\%20on\%20violation\%20of\%20 fundamental $\% 20$ rights $\% 20$ and $\% 20$ freedoms $\% 20$ arising $\% 20$ from\%20October_1_eng.pdf. Accessed 6 Sept 2020

Delanty G (2019) What does self-determination mean today? The resurgence of nationalism and European integration in question. Global Discourse: An interdisciplinary journal of current affairs 9(1):93-107

Delledonne G (2011) Speaking in name of the constituent power: the Spanish constitutional court and the new Catalan Estatut. Perspect Federal 3(1):1-14

Dowling A (2014) Accounting for the turn towards secession in Catalonia. Int J Iber Stud 27(2):219-234

El P (2017) Address to the nation by Felipe VI. 4 October. Available at: https://elpais.com/elpais/2017/10/03 /inenglish/1507063595 266495.html. Accessed 6 Sept 2020

Elliot JH (2018) Scots and Catalans: union and disunion. Yale University Press, New Haven, CT and London

Enoch D (2014) Authority and reason-giving. Philosophy and phenomenological research 89:296-332. Available at SSRN: https://ssrn.com/abstract=2606995. Accessed 6 Sept 2020

Fuller LL (1969[1964]) The morality of law, revised edition. Yale University Press, New Haven, CT and London

Garrido-Muñoz A (2018) Prime minister v. parliament of Catalonia. Am J Int Law 112(1):80-88. https://doi. org/10.1017/ajil.2018.18

Griffiths RD, Guillen Alvarez P, Martinez i Coma F (2015) Between the sword and the wall: Spain's limited options for Catalan secessionism. Nations Nationalism 21(1):43-61. https://doi.org/10.1111/nana.12102

Guardian The (2019) Spanish police clash with thousands of Catalan protesters in Barcelona. 27 October. Available at: https://www.theguardian.com/world/2019/oct/27/spanish-police-clash-with-thousands-ofcatalan-protestors-in-barcelona. Accessed 6 Sept 2020

Guibernau M (2013) Secessionism in Catalonia: after democracy. Ethnopolitics 12(4):368-393

Habermas J (1994[1992]) Faktizität und Geltung: Beiträge zur Diskurstheorie des Rechts und des demokratischen Rechtsstaats. Suhrkamp, Frankfurt am Main

Hart HLA (1882) Essays on Bentham: studies in jurisprudence and political theory. Oxford University Press, New York

Hart HLA (1994[1961]) The concept of law, 2nd edn. Oxford University Press, New York

Hershovitz S (2003) Legitimacy, democracy, and Razian authority. Legal Theory 9:201-220 
Hershovitz S (2011) The role of authority. Philosophers' Imprint 11(7):1-19

Himma KE (2007) Just 'Cause You're Smarter than Me Doesn't Give You a Right to Tell Me What to Do: Legitimate Authority and the Normal Justification Thesis. Oxf J Leg Stud 27(1):121-150

Honig B (2007) Between decision and deliberation: political paradox in democratic theory. Am Polit Sci Rev 101(1):1-17. https://doi.org/10.1017/S0003055407070098

International Trial Watch (2019a) Shadow report human rights council - universal periodic review (third cycle). Available in English at http://internationaltrialwatch.org/wp-content/uploads/2019/07/1907-ITW-ShadowReport-ENG.pdf. Accessed 6 Sept 2020

International Trial Watch (2019b) Factual and legal assessment by international and national observers of the judgment condemning Catalan authorities and social leaders (SCJ 459/2019). Available in English at: https://internationaltrialwatch.org/wp-content/uploads/2019/11/POSICIONAMIENTO_ SENTENCIA 12112019-ingles-carta.pdf. Accessed 6 Sept 2020

Jones E (2017) Catalonia and the problem of identity politics. Survival 59(6):41-46. https://doi.org/10.1080 $/ 00396338.2017 .1399723$

Jones S (2018) Tensions flare at Barcelona protests on anniversary of independence vote. The Guardian, 1 October. Available at: https://www.theguardian.com/world/2018/oct/01/protests-catalonia-first-anniversaryindependence-vote. Accessed 6 Sept 2020

Jones S and Burgen S (2019) Spain's deputy PM tells Catalan president to 'stop telling impossible lies'. The Guardian, 20 October. Available at: https://www.theguardian.com/world/2019/oct/20/spains-deputy-pmtells-catalan-president-to-stop-telling-impossible-lies. Accessed 6 Sept 2020

Ladenson R (1990) In defense of a Hobbesian conception of law. In: Raz J (ed) Authority. Basil Blackwell, Oxford, pp 32-55

López-Basaguren A (2019) Claims for secession in Catalonia. Rule of law, democratic principle and federal alternative. In: López-Basaguren A, Escajedo San-Epifanio L (eds) Claims for secession and federalism: a comparative study with a special focus on Spain. Springer Nature Switzerland AG, Cham, pp 365-388

Margalit A, Raz J (1990) National self-determination. J Philos 87(9):438-461

Marrero Gonzaléz G (2015) Catalonia's independence and the role of the constitutional court: recent developments. Tijdschrift voor Constitutioneel Recht 6(1):86-94

Mueller S (2019) Catalonia: the perils of majoritarianism. J Democr 30(2):142-156

Norman W (2003) Domesticating secession. In: Macedo S, Buchanan A (eds) Secession and self-determination. New York University Press, New York and London, pp 193-237

Nozick R (1974) Anarchy, state, and utopia. Blackwell, Oxford

Oakeshott M (1962) Rationalism in politics and other essays. Methuen \& Co, London

Perales-Garcia C (2013) How did we get here? In: Castro L (ed) What's up with Catalonia? The causes which impel them to the separation. Catalonia Press, Ashfield, pp 105-111

Philpot D (1995) In defense of self-determination. Ethics 105(2):352-385

Rancière J (1999[1995]) disagreement: politics and philosophy, transl. Julie rose. University of Minnesota Press, Minneapolis, MN and London

Rancière J (2006) Democracy, republic, representation. Constellations 13(3):297-307. https://doi.org/10.1111 j.1467-8675.2006.00402.x

Rawls J (1999[1971]) a theory of justice, revised edition. Belknap, Cambridge

Raz J (1979a) Legitimate authority. In: The authority of law: essays on law and morality. Oxford University Press, New York, pp 3-27

Raz J (1979b) The claims of law. In: The authority of law: essays on law and morality. Oxford University Press, New York, pp 28-33

Raz J (1979c) The institutional nature of law. In: The authority of law: essays on law and morality. Oxford University Press, New York, pp 103-121

Raz J (1986) The morality of freedom. Clarendon Press, Oxford

Raz J (1994a) Authority, law, and morality. In: Ethics in the public domain: essays in the morality of law and politics. Oxford University Press, New York, pp 210-237

Raz J (1994b) The obligation to obey: revision and tradition. In: Ethics in the public domain: essays in the morality of law and politics. Oxford University Press, New York, pp 341-354

Raz J (1999) Practical reasons and norms. Oxford University Press, New York

Raz J (2006) The problem of authority: revisiting the service conception. In: Between authority and interpretation: on the theory of law and practical reason. Oxford University Press, New York, pp 126-165

Raz J (2010) On respect, authority, and neutrality: a response. Ethics 120(2):279-301. https://doi.org/10.1086 $/ 651426$

Reuters (2017) Juncker says Catalan split would lead to splintering EU. 13 October. Available at: https://www. reuters.com/article/us-spain-politics-catalonia-juncker/juncker-says-catalan-split-would-lead-to-splinteringeu-idUSKBN1CI1SO. Accessed 6 Sept 2020 
Rico G (2012) The 2010 regional election in Catalonia: a multilevel account in an age of economic crisis. S Eur Soc Politics 17(2):217-238

Ruiz Devesa D (2018) Federalism versus nationalism: the case of Catalonia. Federal Debate 31(1):44-46. https://doi.org/10.2478/tfd-2018-0010

Saeed S (2017) Spanish minister: Catalonia's GDP to contract by 30 percent if it secedes. Politico, 18 September. Available at: https://www.politico.eu/article/luis-de-guindos-spain-minister-catalonia-gdp-to-contract-by-30percent-if-it-secedes/. Accessed 6 Sept 2020

Sánchez P (2019) Catalonia, Spain, and Europe are better together project syndicate, 7 November. Available at: https://www.project-syndicate.org/commentary/catalonia-separatism-violates-democracy-rule-of-law-bypedro-sanchez-2019-11. Accessed 6 Sept 2020

Schmitt C (1985) Definition of sovereignty. In: Schwab G (ed) Political theology: four chapters on the concept of sovereignty. MIT Press, Cambridge and London, pp 5-15

Shapiro SJ (2011) Legality. Belknap Press of Harvard University Press, Cambridge and London

Smith A (2019) Catalan leaders' sentences a 'travesty of justice'. The Greens/EFA, 14 October 2019. Available at: https://www.greens-efa.eu/en/article/press/catalan-leaders-sentences-a-travesty-of-justice/. Accessed 6 Sept 2020

Stokes N and Shields C (2019) A week of turmoil in Catalonia: day by day. CatalanNews, 21 October. Available at: https://www.catalannews.com/society-science/item/a-week-of-turmoil-in-catalonia-day-by-day. Accessed 6 Sept 2020

Sunstein C (1991) Constitutionalism and secession. Univ Chic Law Rev 58:633-670

Tobeña A (2017) Secessionist urges in Catalonia: media indoctrination and social pressure effects. Psychology 8(1):77-96. https://doi.org/10.4236/psych.2017.81006

Van der Burg W (1989) The myth of civil disobedience. Praxis International, 287-304. Erasmus working paper series on jurisprudence and socio-legal studies no. 10-04. Available at SSRN: https://ssrn. com/abstract=1668557. Accessed 6 Sept 2020

Waldron J (2003) Authority for officials. In: Meyer LH, Paulson SL, Pogge TW (eds) Rights, culture, and the law: themes from the legal and political philosophy of Joseph Raz. Oxford University Press, Oxford, pp 4570

Warf B, Ferras C (2015) Nationalism, identity and landscape in contemporary Galicia. Space Polity 19(3):256272. https://doi.org/10.1080/13562576.2015.1080425

Wolf RP (1970[1998] In defense of anarchism. University of California Press, Berkeley, CA, Los Angeles, CA and London 